fährtinnen seiner Töchter von anderen Testbullen oder von geprüften Altbullen abstammen. Dieser Nachteil tritt nicht auf, wenn die. Regression der zukánftigen Töchter auf die durchschnittliche Differenz zwischen Töchtern und Zeitgefährtinnen gegen I geht. Die Sire comparison Methode hat diesen Nachteil nicht, und durch eine kleine Abänderung der cumulativen Differenz. methode könnte diese Eigenschaft vermieden werden. $\mathrm{Zu}$ überprüfen ist, wie weit die grössere Genauigkeit der Sire comparison Methode, die theoretisch zu erwarten ist, die höheren Rechenkosten im konkreten Fall aufwiegt.

\title{
UNBIASED ESTIMATION OF THE BREEDING VALUE OF BULLS
}

\author{
K. OsterkoRn. - Institut $f$. Tierzucht und Tierhygiene, Lehrstuhl für Tierzucht, Universität \\ München, BRD.
}

A large percentage of culled cows have low milk yields, which would result in a biased estimation of the breeding value. Under certain assumptions, this bias may be corrected. An unbiased estimation of the breeding value may also be obtained by the mode, since the position of the maximum of the density function is not influenced by the cullings.

\section{ABSTAMMUNGSBEWERTUNG DER ZUCHTSTIERE PROPEKTIV UND RETROSPEKTIV}

F. WeBer. -.-Institut für Tievzucht, Eidgen. Techn. Hochschule, Zürich, Schweiz.

Partial regression coefficients between the breeding values for milk production of 97 Simmental AI-bulls and the breeding values of their sires, dams and granddams were calculated and compared with the theoretical weights of a selection index.

The regression coefficient for sires was close to the theoretical weight. The regression coefficient for dams was closer to expectation when calculated on the dams first lactations only than when calculated on all lactations. It was concluded, that the heritability of average milk production among dams of A I-bulls is lower than among the rest of the population.

\section{HERITABILITÄTSSCHÄTZUNG FÜR DIE MILCHLEISTUNG AUFGRUND DER TÖCHTER-MǓTTER-REGRESSION-ERGEBNISSE UND DAMIT VERBUNDENE PROBLEME}

\author{
E. Dymnicki*, J. Lederer, G. Averdunk. -- Bayerisches Landesanstalt für Tierzucht 8011 \\ Grub, BRD. \\ * Als Gastwissenschaftler 193-74 an der BLT. Heimatanschrift : Institut $f$. Tierzucht und \\ Genetik der "Polnischen Akademie für Wissenschaften "in Jastrzebiec bei Warschau (Polen).
}

An 17771 Töchter-Mutter-Paaren des Fleckviehs wurden Heritabilitätsschätzungen nach verschiedenen Methoden (einfache Regression, Intra-Vater-Tochter-Mutter-Regression und Kovarianz väterlicher Halbgeschwister) durchgeführt. Es besteht die generelle Tendenz, dass die Tochter-Mutter-Regression höhere Schätzwerte für die Heritabilität erbringt, als die an gleichem Material errechneten über die Halbgeschwisterähnlichkeit $\left(h^{2}=0,36\right.$ bzw. 0,25 für die umweltkorrigierte Milchmenge).

Stehen Töchter und Mutter jedoch in unterschiedlichen Betrieben, so sinkt die Heritabilität nach der TM-Regression bei $n=1082$ auf 0,26 ab. Auch besteht die Tendenz abnehmender Töchter-Mutter-Regressionen mit zunehmendem Zeitabstand zwischen Töchtern und Müttern. Beide Befunde lassen einen umweltbedingten Anteil der Kovarianz zwischen Töchtern und Müttern vermuten. Für die Beeinflussung des Zuchtwertschätzergebnisses von Bullen durch eine unterschiedliche Vorselektion der Mutter ist diese höhere Heritabilität ebenfalls von Bedeutung. 